\title{
Novel antitumor DNA monoalkylating agents: Synthesis and biological evaluation
}

\author{
Ana F Brito ${ }^{1,2^{*}}$, M Isabel Soares ${ }^{3}$, Mafalda Laranjo ${ }^{1,2}$, A Margarida Abrantes ${ }^{1,2}$, José A Paixão ${ }^{4}$, Ana M Beja ${ }^{4}$, \\ Manuela R Silva ${ }^{4}$, Teresa P Melo ${ }^{3}$, M Filomena Botelho ${ }^{1,2}$ \\ From 16th International Charles Heidelberger Symposium on Cancer Research \\ Coimbra, Portugal. 26-28 September 2010
}

DNA is the molecular target for many of the drugs that are used in cancer therapeutics. Of particular interest are the minor groove binders, a group of DNA interactive agents that bind to specific regions of the genome and show significant toxicity towards cancer cells [1].

Alkylating agents induce permanent DNA damage and exhibit potent antitumor activity. A range of alkylating agents is known including monoalkylating and bifunctional alkylating drugs. The latter were found to crosslink the two complementary strands of DNA, which usually results in more efficacious agents.

New chiral $1 H, 3 H$-pyrrolo[1,2-c] thiazoles were synthesized and screened for their in vitro activity as anticancer agents in three human tumor cell lines, colorectal adenocarcinoma, melanoma and breast adenocarcinoma. (R)-6-Hydroxymethyl-5-methyl-3-phenyl-1 $\mathrm{H}, 3 \mathrm{H}$-pyrrolo $[1,2-c]$ thiazole and the corresponding benzylcarbamate showed selectivity for breast cancer cell lines with $\mathrm{IC}_{50}$ values of $2.4 \mu \mathrm{M}$ and $2.2 \mu \mathrm{M}$, respectively. The latter also showed significant activity against colorectal adenocarcinoma cancer cell lines $\left(\mathrm{IC}_{50}=8.7 \mu \mathrm{M}\right)$. In contrast, the 7-hydroxymethyl-5-methyl-3-phenyl-1 $\mathrm{H}, 3 \mathrm{H}$-pyrrolo $[1,2-c]$ thiazole gave moderate anticancer activity. The performance against breast cancer cell lines $\left(\mathrm{IC}_{50}=1.0\right.$ $\mu \mathrm{M})$ of a potential bisalkylating agent, a (3R)-6,7-bis (hydroxymethyl)-1H,3H-pyrrolo[1,2-c] thiazole, wasn't significantly different from the one observed for the monoalkylanting derivatives indicating that the main mechanism of action may in fact be the monoalkylation process.

\footnotetext{
* Correspondence: anabrito816@gmail.com

'Biophysics/Biomathematics Institute, IBILI - Faculty of Medicine, University of Coimbra, Coimbra, Portugal

Full list of author information is available at the end of the article
}

Author details

'Biophysics/Biomathematics Institute, IBILI - Faculty of Medicine, University of Coimbra, Coimbra, Portugal. ${ }^{2}$ Center of Investigation on Environment, Genetics and Oncobiology (CIMAGO), Faculty of Medicine, University of Coimbra, Coimbra, Portugal. ${ }^{3}$ Department of Chemistry, University of Coimbra, Coimbra, Portugal. ${ }^{4}$ Department of Physics, University of Coimbra, 3004-516 Coimbra, Portugal.

Published: 24 September 2010

\section{Reference}

1. Hurley LH: DNA and its associated processes as targets for cancer therapy. Nat Rev Cancer 2002, 2:188-200.

doi:10.1038/nrc749

Cite this article as: Brito et al: Novel antitumor DNA monoalkylating agents: Synthesis and biological evaluation. BMC Proceedings 2010 4(Suppl 2):P51.
Submit your next manuscript to BioMed Central and take full advantage of:

- Convenient online submission

- Thorough peer review

- No space constraints or color figure charges

- Immediate publication on acceptance

- Inclusion in PubMed, CAS, Scopus and Google Scholar

- Research which is freely available for redistribution

Submit your manuscript at www.biomedcentral.com/submit
Biomed Central 